\title{
HISTOPATHOLOGICAL STUDY OF NON-NEOPLASTIC LESIONS OF NOSE, PARANSAL SINUSES AND NASOPHARYNX
}

\author{
Shah H, Baviskar BP, Dongre SD \\ Department of Pathology, Rural Medical College, Pravara Institute of Medical Sciences (PIMS), Loni, \\ Maharashtra, India.
}

\begin{abstract}
Background: The various lesions of the nose, paranasal sinuses and nasopharynx were subjected to histopathological evaluation over a period of 5 years (2010 to 2015) at the Department of Pathology, in a rural based hospital. Total 84 specimens were studied over the time of 5 years. Methodology: The formalin fixed specimens were received with complete clinical and radiological features. Routine gross examination and required number of sections were taken and stained with hematoxylin and eosin. Result: In the study, 84 cases were of Inflammatory and Non neoplastic lesions. Nasal polyps were the most common lesions with $77(91.67 \%)$ cases. Among the all Nasal polyps, 77 cases, 20 (25.97\%) cases were of Allergic polyp, 50 (64.93\%) cases were of inflammatory polyp, while 7 (9.09\%) cases were of Antrochoanal polyp. 2 cases $(2.38 \%)$ each of Sinusitis and Intradermal naevus. Rhinosporidiosis, Mucocele and Nasolabial cyst comprised of $1(0.77 \%)$ case each respectively. Conclusion: In our study, most common lesions were Nasal Polyps. Most of the cases were presented in $2^{\text {nd }}$ and $3{ }^{\text {rd }}$ decade of life with Male preponderance. Nasal obstruction was the most common clinical presentation in the present study.
\end{abstract}

Keywords: Nose; Paranasal sinuses; Nasopharynx; Non-Neoplastic Lesions.

\section{INTRODUCTION}

We perceive our environment through our sensory receptors like nose. Tumours arising or involving nasal cavity and paranasal sinuses were recognized in time of Hippocrates who distinguished between hard and soft tumours and also believed that treatment shortened the patients life! [1].

Nasal cavity comprises of anterior and posterior part, paranasal sinuses and nasophrynx. Nasopharynx is notably most difficult region to examine and there remains areas which may escape otolaryngologist's routine and more detail examination [2]. Clinically and radiologically benign and malignant lesions are hard to differentiate. Only definitive method is biopsy [3].

A variety of non-neoplastic lesions involve nasal cavity, paranasal sinuses and nasopharynx [4].

Polyps are tumour like lesions in nose which are projections of mucous membrane and develop in association with chronic rhinitis and sinusitis. Clinically polyps are smooth, shiny and present as movable swelling. It is quite impossible to distinguish clinically between simple nasal polyp, polypoidal lesions which are caused by specific granulomatous disease and polypoidal neoplasms [5]. Classification of tumours and tumour like lesions of nasal cavity, paranasal sinuses and nasophar-

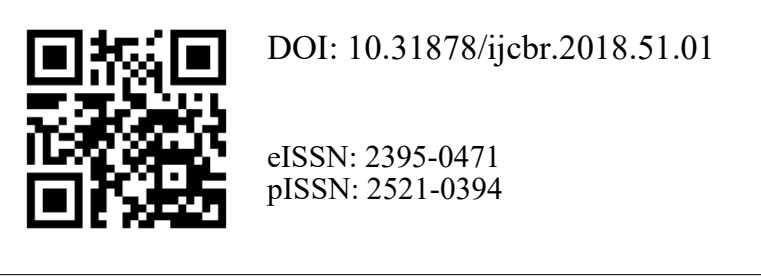

ynx: Malformations, Inflammatory diseases, Benigntumours and Malignant tumours [6].

\section{MATERIAL AND METHODS}

Study design: Descriptive study

Ethics approval: The study was approved by the IEC PIMS (DU)

Study place: The study was conducted in the Department of Pathology at Rural Medical College and Pravara Rural Hospital, Loni

Study period: Over a period of 5 years (2010-2015)

Sample size: Total number of cases were 84 .

Inclusion criteria: All specimens of lesions of Nose, Paranasal sinuses and Nasopharynx received in the Department of Pathology for Histopathological findings.

Collection of sample: All specimens were collected through Departments of ENT and Surgery from Operation Theatre and transported to Department of Pathology, Rural Medical College, Loni, in 10\% Formalin.

Methodology: Clinical data such as the age, sex, complaints and the record of other investigations were obtained from patient. Biopsies of specific sites were received and then processed in the laboratory by routine processing and stained by $H \& E$.

These lesions were evaluated on Haematoxylin \& Eosin stained sections of paraffin embedded $10 \%$ buffered formalin fixed tissue blocks.

Statistical analysis: Data were tabulated and presented in the form of percentage. 


\section{RESULTS}

In the present study, highest incidence of Inflammatory and Non neoplastic cases were in the $2^{\text {nd }}, 3^{\text {rd }}$ and 4 th decade of life which were 16, 22 and 16 cases respectively. There were 4 cases in $1^{\text {st }}$ decade, 10 cases in $5^{\text {th }}$ decade, 6 cases in $6^{\text {th }}$ decade, 9 cases in $7^{\text {th }}$ decade and 1 case in $8^{\text {th }}$ decade of Inflammatory and Non-neoplastic lesions. (Fig 1)

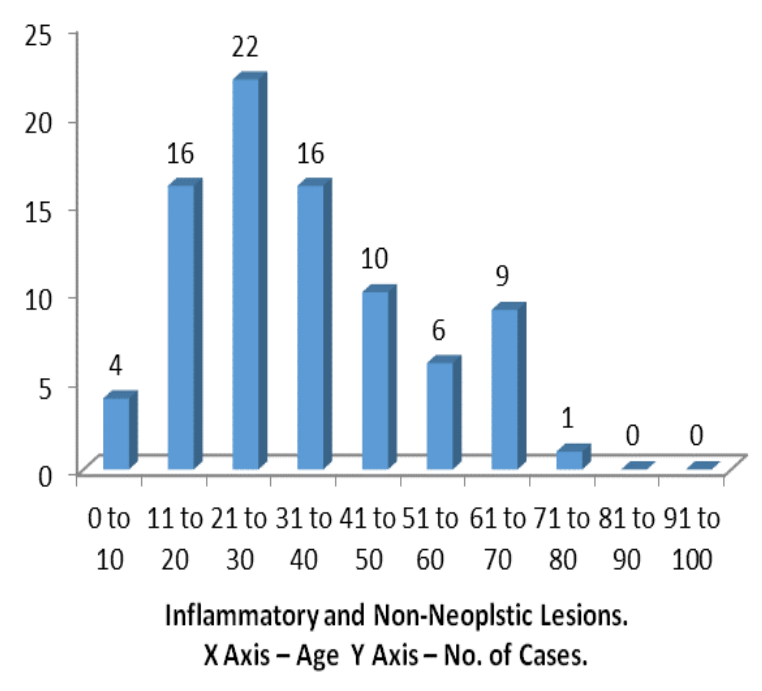

Fig 1. Age Wise Distribution of Inflammatory and Nonneoplastic Lesions

In the present study, Male (44) to female (40) ratio among Inflammatory and Non neoplastic Lesion was 1.1:1.In the present study, the commonest complaint patient presented with was nasal obstruction. Out of 84 cases received, $68(80.95 \%)$ complained of nasal obstruction. The second most common complaint was running nasal mass, $08(9.52 \%)$ cases, followed by sneezing 5 (5.95\%) and nasal discharge 3 (3.57\%).(Fig 2)

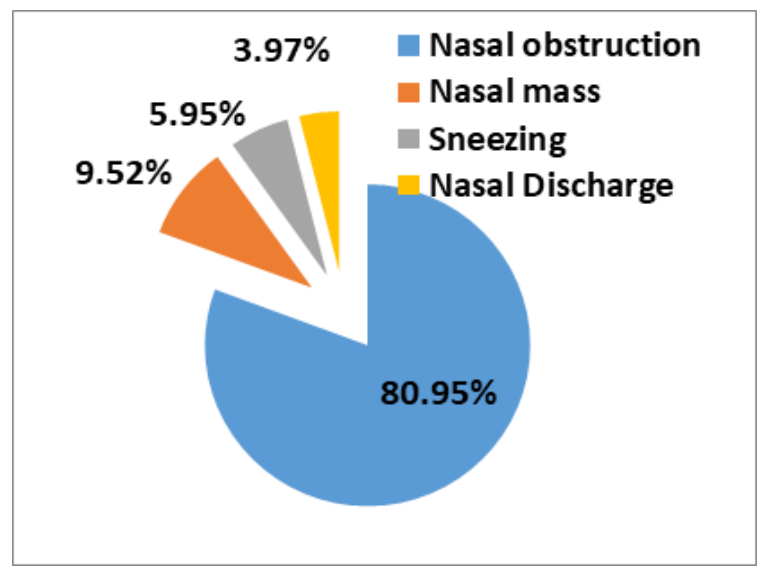

Fig 2. Distribution of Complaints of Patients

In the present study, total 84 cases were of Inflammatory and Non neoplastic lesions. Nasal polyps were the most common lesions with $77(91.67 \%)$ cases, followed by the 2 cases $(2.38 \%)$ each of Sinusitis and Intradermal naevus. Rhinosporidiosis, Mucocele and Nasolabial cyst comprised of $1(0.77 \%)$ case each respectively (Fig 3$)$.

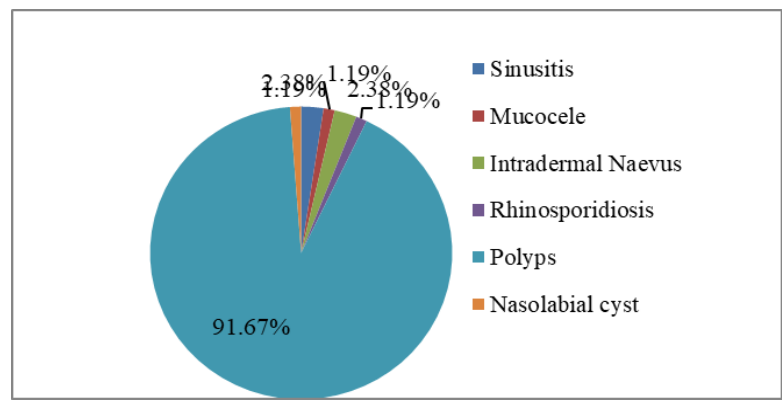

Fig 3. Distribution of Non-neoplastic lesions according to histologic findings.

Among the all Nasal polyps, 77 cases, 20 (25.97\%) cases were of Allergic polyp, 50 (64.93\%) cases were of inflammatory polyp, while $7(9.09 \%)$ cases were of Antrochoanal polyp (Table 1).

Table 1. Distribution of Nasal Polyp According to Histologic Findings.

\begin{tabular}{|c|c|c|}
\hline Nasal Polyp & No.of Cases & $\%$ Cases \\
\hline Allergic polyp & $20 / 77$ & 25.97 \\
\hline Inflammatory polyp & $50 / 77$ & 64.93 \\
\hline Antrochoanal polyp & $07 / 77$ & 9.09 \\
\hline
\end{tabular}

Fig 4. Rhinosporidiosis (H \& E, X100)

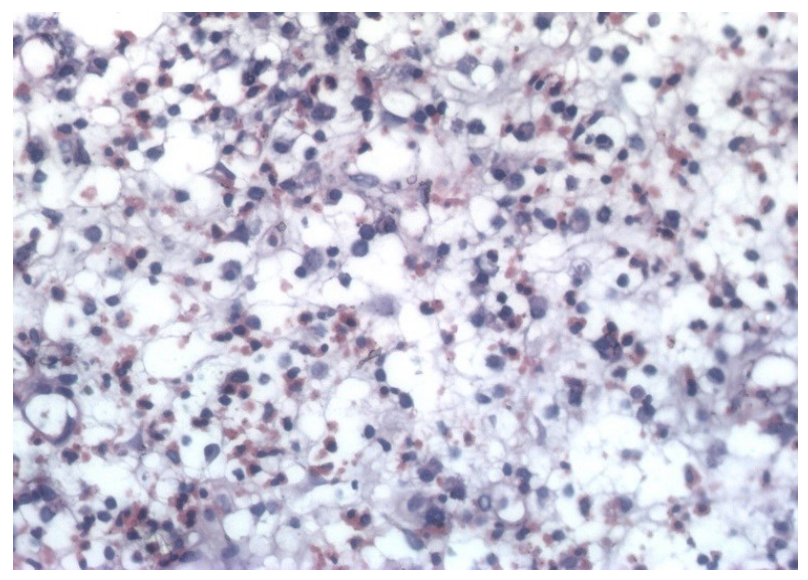

Fig 5. Allergic Polyp (H \& E, X400) 
Table 2. Comparative Study of Incidence of Non-neoplastic lesions according to histopathological Diagnosis.

\begin{tabular}{|c|c|c|c|c|c|c|c|c|}
\hline \multirow[b]{2}{*}{ Diagnosis } & \multicolumn{8}{|c|}{ No. of Cases in Studies } \\
\hline & $\begin{array}{l}\text { Dasgupta A } \\
\text { et al [7] } \\
(1997)\end{array}$ & $\begin{array}{l}\text { Zafar U } \\
\text { et al [4] } \\
(2008)\end{array}$ & $\begin{array}{l}\text { Lathi A et } \\
\text { al [10] } \\
(2011)\end{array}$ & $\begin{array}{l}\text { Bist SS et al } \\
{[15](2012)}\end{array}$ & $\begin{array}{l}\text { Kulkarni } \\
\text { A et al [8] } \\
(2012)\end{array}$ & $\begin{array}{l}\text { Nair S } \\
\text { et al [14] } \\
(2013)\end{array}$ & $\begin{array}{l}\text { Kumari } \\
\text { KMK et al } \\
{[5](2013)}\end{array}$ & $\begin{array}{l}\text { Present } \\
\text { study }\end{array}$ \\
\hline Sinusitis & - & 5 & - & 1 & 1 & 26 & 1 & 2 \\
\hline Mucocele & - & - & 2 & - & - & 4 & - & 1 \\
\hline $\begin{array}{l}\text { Intradermal Nae- } \\
\text { vus }\end{array}$ & 1 & - & - & - & - & - & - & 2 \\
\hline Rhinosporidiosis & 55 & - & 2 & - & 14 & 3 & 2 & 1 \\
\hline Polyps & 110 & 119 & 70 & 53 & 70 & 9 & 44 & 77 \\
\hline Nasolabial Cyst & - & 2 & - & 1 & - & - & - & 1 \\
\hline
\end{tabular}

Table 3. Comparative Study of Incidence of Nasal Polyp in Non-neoplastic Cases.

\begin{tabular}{l|l|l}
\hline Studies & $\begin{array}{l}\text { No. of Cases of Polyps per Non- } \\
\text { neoplastic Cases }\end{array}$ & \% Cases of Polyps \\
\hline Biswas G et al [9](2002) & $9 / 10$ & 90.0 \\
\hline Khan N et al [11](2006) & $120 / 144$ & 83.3 \\
\hline Zafar U et al [4](2008) & $119 / 144$ & 82 \\
\hline Lathi A et al [10] ${ }^{10}(2011)$ & $70 / 80$ & 87.5 \\
\hline Bist SS et al [15] (2012) & $50 / 64$ & 78.1 \\
\hline Nair S et al [14](2013) & $9 / 44$ & 20.4 \\
\hline Present Study (2015) & $77 / 84$ & 91.6 \\
\hline
\end{tabular}

Table No. 4: Comparative Study of Incidence of Nasal Polyp According to Histopathological Diagnosis

\begin{tabular}{|c|c|c|c|c|c|c|c|}
\hline \multirow[b]{2}{*}{ Diagnosis } & \multicolumn{7}{|c|}{ No. of Cases in Studies } \\
\hline & $\begin{array}{l}\text { Dasgupta A } \\
\text { et al }{ }^{7}(1997)\end{array}$ & $\begin{array}{l}\text { Biswas G et } \\
\mathrm{al}^{9}(2002)\end{array}$ & $\begin{array}{l}\text { Bakari A et } \\
\mathrm{al}^{16}(2010)\end{array}$ & $\begin{array}{l}\text { Lathi A et } \\
\mathrm{al}^{10}(2011)\end{array}$ & $\begin{array}{l}\text { Nair S et al }{ }^{15} \\
(2013)\end{array}$ & $\begin{array}{l}\text { Kumari } \\
\text { KMK et al } \\
(2013)\end{array}$ & $\begin{array}{l}\text { Present } \\
\text { Study (2015) }\end{array}$ \\
\hline $\begin{array}{l}\text { Allergic } \\
\text { Polyps }\end{array}$ & 74 & - & 10 & 50 & - & 9 & 20 \\
\hline $\begin{array}{l}\text { Inflammato- } \\
\text { ry Polyps }\end{array}$ & 36 & - & 35 & 20 & - & 35 & 50 \\
\hline $\begin{array}{l}\text { Antrochoanal } \\
\text { Polyps }\end{array}$ & - & 9 & & & 9 & & 7 \\
\hline
\end{tabular}

\section{DISCUSSION}

Histopathological examination is simple and reliable diagnostic procedure for the detection of various lesions of nasal cavity, nasopharynx and paranasal sinuses as most of the lesions are either inaccessible for fine needle aspiration cytology (FNAC).

In the present study, total number of cases were 84 and duration of study was 5 years. Average number of cases per year in the present study were 17.4 cases/year. This finding matches with the study of Dasgupta A [7] with 17.5 cases/year, Kulkarni A [8] with 14.4 cases/year and Zafar U [4] with 20.5 cases/year.

In the present study, age distribution in non-neoplastic cases were between $1^{\text {st }}$ to $8^{\text {th }}$ decades, peak achieving in $2^{\text {nd }}, 3^{\text {rd }}$ and $4^{\text {th }}$ decades. These findings correlate with the findings of Biswas $G$ et al [9], where peak incidence was in $1^{\text {st }}$ and $2^{\text {nd }}$ decades of life, Lathi $A$ et al [10], where peak incidence was in $2^{\text {nd }}, 3^{\text {rd }}$ and $4^{\text {th }}$ decades of life and in the study of Zafar $U$ et al [4], where peak 
incidence was in $1^{\text {st }}, 2^{\text {nd }}$ and $4^{\text {th }}$ decades.

In the present study, male to female ratio was $1.1: 1$ These findings are correlating with the study of Lathi A et al [10] where male to female ratio was $1.35: 1$. In the study of Dasgupta $A^{7}$, male to female ratio was 1.91:1 and in Kulkarni A [8] study, male to female ratio was 2.25:1. In the study of Khan $N$ et al [11] and Zafar $U$ et al [4], male to female ratio was 1.7:1.

In the present study, the commonest complaint patient presented with was nasal obstruction. Out of 84 cases received, $68(80.95 \%)$ complained of nasal obstruction. The second most common complaint was running nasal mass, $08(9.52 \%)$ cases, followed by sneezing $5(5.95 \%)$ and nasal discharge $(3.57 \%)$. In other studies by Biswas $\mathrm{G}$ et al [9], Panchal L et al [12], Lathi A et al [10], Khan $\mathrm{N}$ et al [11], Kulkarni A et al [8] and Shah SN et al [13] Nasal Obstruction was the most common presenting complaint.

In the present study, most common Non-neoplatic lesion was Nasal Polyp comprising of 77 cases, followed by 2 cases each of Sinusitis and Intradermal Naevus. In other studies as mentioned in Table 2 commonest Nonneoplastic lesion was Nasal Polyp. In the study of Dasgupta A et al [7], Lathi A et al [10], Kulkarni A et al[8] and Kumari KMK et al [5], second most common lesion was Rhinosporidiosis. In the study of Nair S et al [14], cases of Sinusitis were more common than Polyp as the study was based on clinical findings.

In the present study, 77 out of 84 Non-neoplastic cases were Nasal polyps (91.6\%). These finding correlate with the study of Biswas $\mathrm{G}$ et al [9] (90\%), Lathi A et al [10] $(87.5 \%)$, Khan N et al [11] $(83.3 \%)$ Zafar U et al [4](82\%), Bist SS et al [15] (78.1\%). In the study of Nair $S$ et al [14] lowest percentage of nasal polyps (20.4\%) were noted. (Table 3 )

In the present study, inflammatory polyp (50 cases) was the most common among the all polyps, followed by the allergic polyp (20 cases). These findings were related with the other studies like Bakari A et al [16], where 35 cases were inflammatory polyp and 10 cases were Allergic polyp, Kumari KMK et al [5], where 35 cases were inflammatory polyp and 9 cases were Allergic polyp. In the study of Dasgupta A et al [7] and Lathi A et al [10], Allergic polyps were more than inflammatory polyps. Biswas $G$ et al [9] and Nair S et al [14], noted Antrochoanal polyps only (Table 4 ).

\section{CONCLUSION}

In our study, most common lesions were Nasal Polyps. Most of the cases were presented in $2^{\text {nd }}$ and $3^{\text {rd }}$ decade of life with male preponderance. Nasal obstruction was the most common clinical presentation in the present study.

\section{REFERENCES}

1. Bosch ABV, Genaida F. Cancer of the Nasal Cavity. Cancer.1979; 37(II): 1458-63.

2. Dawes JBD, Harkine DG, Marshall NP, Von Miert, PG. Malignant Disease of Nasopharynx. J. Laryng Otol. 1969; 85: 211-38.

3. Sharmogratnam K, Sobine LH. Histological Typing Of Upper Respiratory Tract Tumours. International Histological Classification of Tumours 1978; 19.
4. Zafar U, Khan K, Afroz N, Hasan SA. Clinicopathological study of Non-Neoplastic Lesions of Nasal Cavity andParanasal Sinuses. Indian J. of PatholMicrobiol 2008;51(1): 26-9.

5. KalpanaKumari MK, Mahadeva KC. Polypoidal Lesion in Nasal Cavity. J.Clinical And Diagnostic Research 2013;7(6) :1040-42.

6. Bruce MW. Tumors of Upper Respiratory Tract, Nasal Cavity, Paranasal Sinuses and Nasopharynx. In: Fletcher CDM. Diagnostic Histopathology of Tumours. Churchill Livingstone 2007:3 ${ }^{\text {rd }}$ Edi. 84.

7. Dasgupta A, Ghosh RN, Mukherjee C. Nasal polyps -Histopathologic spectrum. IJO \& HNS 1997;49(1): 32-37.

8. Kulkarni AM, Mudholkar VG, Acharya AS, Ramteke RV. Histopathological study of lesions of nose and paranasal sinuses. IJO \& HNS 2012; 64 (3): $275-279$.

9. Biswas G, Ghosh SK, Mukhopadhyay S, Bora H. A clinical study of nasopharyngeal masses. IJO \& HNC 2002; 54(3): 193-5.

10. Lathi A, Syed MMA, Kalakoti P, Qutub D, Kishve SP. Clinicopathological profile of sinonasalmasses: a study from a tertiary care hospital of India. Acta Oto rhinolaryngologica Italica 2011;31:372-7.

11. Khan N, Zafar U, Afroz N, Ahmad SS, Hasan SA. Masses of nasal cavity, paranasal sinuses and nasopharynx : A clinicopathological study. IJO \& HNS 2006;58(3):259-63.

12. Panchal L, Vaideeswar P, Kathpal D, Madiwale CV, Prabhat DP. Sino-nasal epithelial tumors. J Postgard Med March 2005;51(1):30-4.

13. Shah SN, Goswami Y. Study of Lesions of Nasal cavity, Nasopharyx and Paranasal Sinuses by Histological Examination. Gujarat Medical Journal 2012;67(2):70-2.

14. Nair S, James E, Awasthi S, Nambiar S, Goyal S. A Review of the Clinicopathological and Radiological Features of Unilateral Nasal Mass. Indian J. Of Otolaryngol, Head Neck Surg 2013; 65(2):199-204.

15. Bist SS, Varshney S, Baunthiyal V, Bhagat S, Kusum A. Clinico?Pathological Profile of Sinonasal Masses: An experience in tertiary care hospital of Uttarakhand. National Journal of Maxillofacial Surgery.2012;3(2):180-6.

16. Bakari A, Afolabi OA, Adoga AA, Kodiya AM, Ahmad BM. Clinico-pathological profile of sinonasal masses: an experience in national ear care center Kaduna, Nigeria. BMC Research Notes 2010;3:186. 